\title{
ORALITY, WRITING AND HISTORY: THE LITERATURE OF THE BUGIS AND MAKASAR OF SOUTH SULAWESI (INTRODUCTION TO SPECIAL ISSUE)
}

\author{
Stephen C. Druce \\ The Academy of Brunei Studies, Universiti Brunei Darussalam, \\ Tungku Link, Gadong BE 1410, Brunei \\ email: stephen.druce@ubd.edu.bn
}

Published online: 15 September 2016

To cite this article: Druce, S. C. 2016. Introduction to special issue. In Orality, writing and history: The literature of the Bugis and Makasar of South Sulawesi, ed. Druce, S. C. International Journal of Asia Pacific Studies 12 (Supp. 1): 1-5, http://dx.doi.org/10.21315/ijaps2016.12.s1.1

To link to this article: http://dx.doi.org/10.21315/ijaps2016.12.s1.1

The Bugis and Makasar peoples are the two largest ethnic groups of South Sulawesi, Indonesia, numbering about 4 million and 1.7 million respectively. Many people think of them as sailors and adventurers who traded and settled throughout the Indonesian-Malay Archipelago. While this is true of some Bugis and Makasar, such activities were undertaken by a relatively small number of individuals and no earlier than the 17th century. As Christian Pelras (1996: 3-4) remarks, the Bugis have long "been among the most imperfectly known of the Insulindian peoples," while the Makasars have been identified mainly with inhabitants of the port city, Makassar. ${ }^{1}$ However, most Bugis and Makasar are farmers, and for centuries the organised cultivation of wet-rice has played a central role in their economic and cultural lives. The Bugis and Makasar did not convert to Islam until the early 17 th century, and while Islam is an important part of their cultural identity, both groups have retained significant elements of their indigenous, pre-Islamic heritage. Both also have a rich literature, some of which contains historical information dating from about $1400 \mathrm{CE}$ and records the development by these two Austronesian-speaking peoples of large agrarian kingdoms based on indigenous cultural and political precepts. 
While Bugis and Makasar literature has long been a subject of scholarly attention, like the peoples themselves, it yet remains poorly understood. The existence of thousands of Bugis and Makasar manuscripts suggests a predominantly written culture; however, as will become clear in this issue, the written word has by no means replaced oral tradition in Bugis and Makasar literature. There is a complex relationship between orality and writing, and the former has traditionally been viewed as no less prestigious than the latter (Pelras, transl. Macknight 2016). Likewise, the Bugis and Makasar chronicles, which are noted for their rational, matter-of-fact styles, are unrepresentative of Bugis and Makasar historical literature, most of which is in the form of short works of one to three pages in length, and derived from oral tradition.

This special issue of the International Journal of Asia Pacific Studies brings together a wide range of articles from some of the world's leading scholars of Bugis and Makasar literature, history and archaeology. ${ }^{2}$ A prelude to this collection of articles is a short paper about Christian Pelras, written by Campbell Macknight, that serves two purposes. The first is to commemorate Christian Pelras and his valuable work on the Bugis, work that spanned some 40 years. The second serves to introduce Macknight's English translation of one the most important and influential articles written by Pelras: "Orality and Writing among the Bugis."

"Orality and Writing among the Bugis" was first published in 1979 as "L'oral et L'écrit dans la Tradition Bugis" in the journal Asie du Sud-est et Monde Insulindien. Although often cited by those working on South Sulawesi, the relative obscurity of its publication and the medium used has made it difficult to access for many scholars. Consequently, the article has not received the attention it deserves. Macknight's translation now makes this valuable work available to a wider audience.

Christian Pelras was the first to explore the relationship and interaction between orality and writing in South Sulawesi, and his seminal article sets out his conclusions. It presents a wealth of insights and data on the topic that has influenced later related studies and played an important role for historians attempting to understand South Sulawesi sources. ${ }^{3}$ Essentially, Pelras presents a masterful demonstration of the complex relationship between the oral and written registers and the absence of a boundary between them. This special issue is dedicated to the memory of Christian Pelras (1934-2014).

Macknight's own paper, "The Media of Bugis Literacy: A Coda to Pelras," follows and presumes a prior reading of Pelras' "Orality and Writing." He investigates a specific aspect of Bugis literacy that is the surfaces and tools used in writing the Bugis script. Macknight notes that in 
the record of Bugis literacy there is little printed material, and then takes the reader on an exploration of the various media used by the Bugis. This includes palm-leaf (the original media), paper, various silverware, pottery and modern examples from printed materials. He provides photographic examples of many of these media, and where relevant provides transcriptions and translations. Interestingly, he provides examples of how the script is being used today in education by the Pesantren As'adiyah, in Wajo. Other examples of modern use appear hard to find, and Macknight laments the fact that in modern South Sulawesi literacy in the script is rare.

The central focus of Stephen Druce's paper, "Transmitting the Past in South Sulawesi: The hikajat Sawitto and Other Bugis and Makasar Historical Works," is a Malay language text typed in the Latin script. He suggests that a Dutch colonial official, perhaps A. A. Cense, commissioned this unusual document (almost all Bugis historiography is in the Bugis language) in the 1930s. This work provides important insights into how the past was transmitted in South Sulawesi, and the relationship between orality and writing in historical sources. The discussion of the text is framed within this broader context and begins with an overview of Bugis and Makasar historical prose works. This concentrates mainly on the few longer written compositions dating from the 17th to 20th centuries, and the diverse factors that influenced their creation at different times in history. According to Druce, these small number of written compositions represent an exception in the corpus of Bugis and Makasar historical sources, and it is the oral sources used to construct the Malay language text that are most representative. He argues that for 500 years after writing was developed, orality remained the primary medium for transmitting the past in South Sulawesi. Druce presents a translation of the text, identifies its constituent elements, and investigates what these can tell us about Sawitto's past.

Bugis genealogies are probably the largest genre of Bugis writings and, for the Bugis themselves, the most important. Ian Caldwell and Kathy Wellen's article, "Family Matters: Bugis Genealogies and Their Contribution to Austronesian Studies," presents an overview and analysis of these genealogies and their functions. This article makes not only a valuable contribution to the understanding of pre-modern South Sulawesi, but also to the wider Austronesian-speaking world. As the authors explain, these genealogies are "records of affinal and consanguineal relations" of the Bugis elite and provide an account of Bugis political (and to a lesser degree, economic) history. They also reveal what was important to this elite, namely status, precedence and origins, which the authors argue are classical Austronesian concerns. Some of these genealogies contain historical data that reaches back to around 1400 , some 200 years before elite conversion to 
Islam. As the authors demonstrate, early Bugis genealogies offer a rare window through which we can study literate, un-Indianised Austronesians.

In "The Inside View on Makassar's 16th to 17th Century History: Changing Marital Alliances and Persistent Settlement Patterns," David Bulbeck combines his archaeological and statistical skills with Makasar texts in order to reassess his earlier work on the complex marriage politics of Makassar, a kingdom born from a union between the polities of Gowa and Talloq. This reassessment is made possible by scholarly translations of Makasar texts by William Cummings that supersede earlier, less reliable translations. Bulbeck demonstrates that the kinship system in the upper echelons of Makassar society was patrilineal. His analysis then reveals the spatial extent and influence of the major Makassar patrilines and how their geographic scope shifted during three distinct historical phases in line with Gowa's changing fortunes. Bulbeck's many insights into the complexities of these marriage alliances are linked to a discussion of the archaeological landscape that utilises the rich data he has collected over the years.

Nurhayati Rahman's contribution concerns a largely unexplored topic in South Sulawesi literature, namely the adaption and transformation of foreign literary works. Her focus is the pau-paunna Indale Patara, a long, heroic fantasy about the vicissitudes and quest of a young prince. The story came to the Bugis via the Malays, perhaps as early as the 17th century, as the well-known hikayat Inderaputera, which in turn was based on an earlier Indian work. In her analysis, Nurhayati demonstrates how the Bugis turned the pau-paunna Indale Patara into a literary work of their own. She highlights and explains the numerous Bugis cultural concepts found in the story, and shows how these concepts interact with Sufism. In particular, the central character of Indale Patara represents the Bugis perception of what constitutes the "perfect man" (Al-Insan al-Kamil).

In "Narratives of Sexuality in Bugis and Makasar Manuscripts," Muhlis Hadrawi draws our attention to a little known genre of literature known as assikalaibineng: repositories of sexual knowledge for a husband and wife. He argues that assikalaibineng texts are derived from a combination of Bugis and Makasar knowledge of sexuality and sexual relations and Islamic values, specifically Sufi teaching introduced in the 17th century by the Makasar mystic Syekh Yusuf. Knowledge of these texts and their contents appears to have been largely restricted to political and religious elites who followed Sufi tariqa. Assikalaibineng texts provide explicit sexual guidance for a couple on a variety of sexual practices, excerpts of which are presented in the article. This guidance is not concerned simply with sexual intercourse but with psychological and 
religious actions that must be completed before and afterwards, in order to perfect lovemaking.

\section{ENDNOTES}

* Stephen Druce obtained his PhD in Southeast Asian history from the Centre for South-East Asian Studies at Hull University. He has published international articles and book chapters on the history, archaeology and literature of South Sulawesi and early Borneo. He is the author of The Lands West of the Lakes: A History of the Ajattappareng Kingdoms of South Sulawesi, 1200 to 1600 CE (KITLV Press, 2009) and Sebuah Sejarah Sulawesi Selatan dan Tradisi Lisan dan Tulisan, Abad ke-13 hingga ke-17 (Penerbit Ombak and KITLV Jakarta, in press). He currently teaches Southeast Asian and Brunei history at Universiti Brunei Darussalam, where he is Programme Leader in Graduate Studies and Research in the Academy of Brunei Studies.

1 Here, and in the articles that follow in this issue, Makasar (with one "s") refers to the ethnic group of that name and their language; Makassar refers to the historical kingdom and the capital of South Sulawesi, formerly Ujung Pandang.

2 Roger Tol and Sirtjo Koolhof were unable to contribute to this issue due to constraints on their time, while William Cummings is no longer working on South Sulawesi.

3 For example, see Druce (2009: 37-8).

\section{REFERENCES}

Druce, S. C. 2009. The lands west of the lakes: A history of the Ajattappareng Kingdoms of South Sulawesi, 1200 to 1600 CE. Leiden: KITLV Press.

Pelras, Ch. 1979. L'oral et l'ecrit dans la tradition Bugis. Asie du Sud-est et Monde Insulindien 10 (2-4): 271-297. . 1996. The Bugis. Oxford: Blackwell. , trans. Macknight, C. C. 2016. Orality and writing among the Bugis. In Orality, writing and history: The literature of the Bugis and Makasar of South Sulawesi, ed. Druce, S. C. International Journal of Asia Pacific Studies 12 (Supp 1): 13-51, http://dx.doi.org/10.21315/ijaps2016.12.s1.3. 